\title{
Effect of Irrigation with Agricultural Drainage Water on Yield and Quality of Some Rice Varieties (Oryza sativa L.)
}

\author{
M. A. Gomaa', I. F. Rehab ${ }^{1}$, G. Abdel-Nasser ${ }^{1}$, A. Ebaid ${ }^{2}$, B. A.M. Elyamny ${ }^{2}$ \\ ${ }^{1}$ Faculty of Agriculture (Saba Basha), Alexandria University. \\ ${ }^{2}$ Rice Researches Department, Field Crop Research Institute, ARC.
}

\begin{abstract}
The present investigation included field experiments executed at the experimental farm (Abees region) of the Faculty of Agriculture (Saba-Basha), Alexandria University, Egypt, during both 2012 and 2013 growing seasons. Experiments were carried out to study the effect of irrigation with agricultural drainage water and/or canal water on yield and quality of four rice varieties (Oryza sativa L.). Five irrigation treatments were practiced as follow; (T1) Irrigation throughout the season using agricultural drainage water, (T2) Irrigation with agricultural drainage water then using canal water in sequence, (T3) Using agricultural drainage water for irrigation till end of the vegetative growth stage and the canal water starting from reproductive stage,(T4) Using canal water at the vegetative growth stage and agricultural drainage water right before panicle initiation, (T5) Irrigation throughout the season with canal water. Four Egyptian rice cultivars namely; Hybrid 1(SK 2034), Sakha 104, Giza 177, Giza 178 were used. Some growth characters, grain yield and its component characters, some yield related characters, and some grain quality characters were subjected to determine the effect of these two variables. The main results showed that, increasing of the dose of canal irrigation water starting from T1 (irrigation throughout the season using agricultural drainage water) and ending by 75 (irrigation throughout the season by canal water) significantly increased the mean values of most of studied characters and maximized by using T5 in 2012 and 2013 seasons. Meantime, the differences between the effect of T5 and T3 (using agricultural drainage water for irrigation at the vegetative growth period and the canal water right before reproductive stage) were not significant in case of most studied characters. The highest grain yields was obtained for Hybrid $1(0 .$. t/fed. ) .rice cultivars while; Giza 177 rice cultivar produced the lowest grain yield (3.18 t/fed.) during both seasons But also, all milling characters and quality characters Giza 178 rice cultivars obtained the heist values than the other cultivars. These findings assure the great amount of genetic variations between the tested cultivars. Interaction between irrigation treatments and rice cultivars had significant effect on most tested characters except harvest index in both seasons and grain yield (ton/fed.) in 2013 season only.
\end{abstract}

Keywords: rice cultivars, agricultural drainage water, rice yield and quality

\section{INTRODUCTION}

Rice (Oryza sativa L.) is the most important food for more than $50 \%$ of the world's population, and it is grown on almost 155 million ha worldwide. In Egypt, rice cultivation takes place in Egyptian Nile delta especially in the northern part. Due to the intrusion of sea-water, most of agricultural lands in the northern Nile delta are affected by different degrees of salinity. In these areas, rice production helps to leach the salt from upper soil layers and thus reclaim the land for agricultural activities. Because of limited water resources, the government of Egypt has tried to limit rice cultivation. Egyptian government aims to reduce rice fields from 1.7 million fed. To only 1.00 million fed. as a part of a strategy to save irrigation water (Allam and Wahba, 2008). It is well known that at the terminal of the irrigation canals, the farmers suffer from sharp decrease in irrigation water accordingly they obligatory use drainage water directly by pumping it from drains close to their fields. This is termed unofficial reuse. Estimates of the amount of drainage water unofficially used for irrigation range from 2800 million $\mathrm{m}^{3}$ to 4000 million $\mathrm{m}^{3}$ per year (FAO, r..6). Water availability for irrigation could be enhanced through judicious and proper recycling of drainage waters for irrigation. Considerable amounts of such water are available in various places in the world, including Australia, Egypt, India, 
Israel, Pakistan, and USA. Waters generally classified as unsuitable for irrigation can, in fact, be used successfully to grow crops without long-term hazardous consequences to crops or soils, with the use of improved farming and management practices. The development of rice varieties with increased salt tolerance and the adoption of new crop and water management strategies will further enhance and facilitate the use of saline waters for irrigation and crop production, while keeping soil salinity from becoming excessive. In Egypt, ElMowelhi et al. (2006) reported that Egypt produces approximately 2.4 million $\mathrm{m}^{3}$ of secondary treated wastewater (TWW) annually, used for irrigation directly or indirectly by blending drainage water (BDW). The annual re-use of BDW is approximately 4 million $\mathrm{m}^{3}$. TWW can be used for high production of oil crops compared to canal water, while BDW can be used for high production of tolerant crops. It is better to use alternative irrigation with canal water under a drip irrigation system to maximize crop production and minimize the adverse effects of such water in field crops quality. In the North Nile Delta, marginal water can be safely used without significant negative impact on the environment. As long as, the national policy of water management, the scarcity of water irrigation, the high soil salinity in North delta and the high profit of rice cultivation. The present study aimed to evaluate the effect of irrigation using drainage water or the mixture between canal and drainage waters at different growth stages on rice plant also yield, yield components and quality of grains of four rice cultivars.

\section{MATERIALS AND METHODS}

Field experiments, were conducted at the Experimental Farm (Abees region) of Faculty of Agriculture (Saba-Basha), Alexandria University, Egypt, located at Abees region during 2012 and 2013 growing seasons. The experiment was carried out to study the effect of irrigation with agricultural drainage water on yield and quality of some rice (Oryza sativa L.) varieties namely (Hybrid 1, Sakha 104, Giza 177 and Giza 178) which are varied in their genetic characters.

\section{Experimental design}

This field experiment was carried out in a strip plot design in both seasons with three replicates. Main plots (columns) were devoted to Irrigation treatments as follows:

(T1) Irrigation throughout the season using agricultural drainage water,

(T2) Irrigation with agricultural drainage water then using canal water in sequence,

(T3) Using agricultural drainage water for irrigation at the vegetative growth period ( about 45 days after transplanting) and then canal water till harvesting,

(T4) Using canal water at the vegetative growth (about 45 days after transplanting) and then agricultural drainage water till harvesting and

(T5) Irrigation throughout the season using canal water.

While, cultivars were allocated to sub plot (rows) including the following :

1. Hybrid 1, (SK 2034), suitable for normal and saline soils.

2. Sakha 104, suitable for normal and saline soils.

3. Giza 177, not recommended for saline soils.

4. Giza 178, suitable for normal and saline soils and water shortage. 


\section{Cultural practices}

\section{Nursery}

The four cultivars were grown in well prepared seedbed. Seed bed was tillaged three times, then dry leveled and water leveled. Nitrogen fertilizer was applied at the rate of $60 \mathrm{~kg} \mathrm{~N} / \mathrm{fed}$ as Urea form $(46 \% \mathrm{~N})$ on dry soil before flooding and nursery was not fertilized with super phosphate $\left(15.5 \% \quad \mathrm{P}_{2} \mathrm{O}_{5}\right)$ because the previous crop was Egyptian clover (Trifolium alexandrinum). Zinc sulfate at the rate of $10 \mathrm{~kg} / \mathrm{fed}$ was applied after puddling. Seeds were soaked in enough water for 24 hours then incubated for 48 hours to enhance germination. The peregrinated seeds were broadcast into the seed bed at the rate of $7-10 \mathrm{~kg}$ seeds/fed. for rice cultivar Hybrid 1 and at the rate of $40-60 \mathrm{~kg}$ /fed. for other cultivars. For controlling weeds, herbicide (Saturn 10\%) at the rate of 2 liters/fed was applied 5 days after seeding into $3 \mathrm{~cm}$ water depth. Rice seedlings were carefully pulled from the nursery after 25 days from seeding and transplanted to the permanent filed.

\section{The permanent field}

The permanent field was mechanically tillaged and dry leveled. The experimental site was divided into 60 plots each plot was $2 \times 3 \mathrm{~m}^{2}$. Columns were irrigation treatments. Drainage water was pulled up from the drain next to the experimental field. Two seedlings, ( 25 days old) were lined transplanted into plots according to the planting spacing, for the four cultivars $20 \times 20 \mathrm{~cm}$ between rows and hills. Thiobencarb (Saturn 50\%) as herbicide at the rate of 2 liters/fed was applied 4 days after transplanting for weed control. All plots were continuously flooded with 5-7 cm water depth throughout the growing season except at the time of the second dose of nitrogen application. All remaining agricultural treatments were applied as the recommendations of the National Rice Campaign booklet (2012) for hybrid variety. Fifteen days before maturity, all plots were flushed and irrigation was stopped two weeks before harvesting.

\section{Soil and Water analyses}

Before transplanting the rice seedlings in the permanent field, soil samples were collected randomly from $0-30 \mathrm{~cm}$ depth from the experimental sites, air dried and ground to pass $2 \mathrm{~mm}$ sieve. Another soil samples were also collected from each strip individually before drying the permanent field for harvesting. Sub samples were then taken to the laboratory and prepared prior to the mechanical and chemical analysis including heavy metals according to Black et al. (1965) .Samples were analyzed at "Soil, Water and Plant Analysis Laboratory" of Soil and Agricultural Chemistry Department, Faculty of Agriculture -Saba Basha, Alexandria University. Heavy metals analyzing showed that the all soil samples didn't contain of heavy metals neither nor all water samples. Heavy metals analyzing were conducted at the Central Laboratory, Faculty of Agriculture, Alexandria University.

The soil were analyzed for the determination of particles size distribution (sand, silt and clay) by hydrometer method (Black et al., 1965). The electrical conductivity $(E C)$ of $1: 1$ soil-water ratio extract was measured by conductivitymeter, the $\mathrm{pH}$ was measured in $1: 1$ soil water suspension by $\mathrm{pH}$ meter, the concentrations of water soluble cations $\mathrm{Ca}^{++}, \mathrm{Mg}^{++}$were determined by $\mathrm{Na}_{2}$ EDTA method, those of $\mathrm{Na}+\mathrm{K}+$ were measured by flame photometer, the content of Bicarbonate was determined by titration with standard $\mathrm{HCl}$ acid 
solution, the chloride by titration with $\mathrm{AgNO}_{3}$ solution and $\mathrm{SO}_{4}{ }^{+2}$ was obtained by the difference(Black et al., 1965). The available K, P, N were extracted with 0.5 $\mathrm{M} \mathrm{NaHCO}$ then $\mathrm{K}$ was measured by flame photometer, $\mathrm{P}$ and $\mathrm{N}$ were measured by colorimetric method (Jackson, 1973).

The analytical results of the soil sample collected before and after cultivation are shown in Tables (1 and 2).

Water samples were collected from both irrigation canal and drainage water and chemically analyzed according to Jackson (1973) as shown in Table (3). Quality of the irrigation water was determined according to the methods described in Wilcox (1958) and FAO (1976). The water quality parameters are; Soluble Sodium Percentage (SSP), Sodium Adsorption Ratio (SAR), Residual Sodium Carbonates (RSC), Soluble Magnesium Percentage (SMgP) and Potential Salinity (PS).

Table (1). Soil mechanical and chemical characters of the experimental site before cultivation in 2012 and 2013 growing seasons

\begin{tabular}{|c|c|c|}
\hline Characters & 2012 & 2013 \\
\hline \multicolumn{3}{|l|}{ Particle size distribution (\%), } \\
\hline Sand & 11.2 & 11.5 \\
\hline Silt & 33.2 & 33.7 \\
\hline Clay & 55.6 & 55.8 \\
\hline Soil texture & Clay & Clay \\
\hline $\mathrm{pH}(1: 1$, soil: water suspension ) & 7.95 & 7.15 \\
\hline EC (1:1, soil: water extract), dS/m & 5.48 & 5.71 \\
\hline \multicolumn{3}{|l|}{ Soluble Cations (meq/l) } \\
\hline $\mathrm{Ca}^{++}$ & 7.83 & 8.30 \\
\hline $\mathrm{Mg}^{++}$ & 15.93 & 16.35 \\
\hline $\mathrm{Na}^{+}$ & 27.82 & 30.05 \\
\hline $\mathrm{K}^{+}$ & 1.75 & 1.8 \\
\hline \multicolumn{3}{|l|}{ Soluble Anions (meg/l) } \\
\hline $\mathrm{HCO}_{3}^{-}$ & 1.98 & 1.97 \\
\hline $\mathrm{Cl}^{-}$ & 6.88 & 6.78 \\
\hline $\mathrm{SO}_{4}^{--}$ & 45.53 & 47.80 \\
\hline Available K (mg/kg) & 1125.0 & 1127.0 \\
\hline Available P (mg/kg) & 29.30 & 28.90 \\
\hline Available N (mg/kg) & 68.29 & 67.94 \\
\hline
\end{tabular}


J. Adv. Agric. Res. (Fac. Agric. Saba Basha)

Table (2). Soil chemical characters of the experimental site after cultivation in 2012 and 2013 growing seasons

\begin{tabular}{|c|c|c|c|c|c|c|c|c|c|c|}
\hline & \multicolumn{2}{|c|}{ T1 } & \multicolumn{2}{|c|}{$\mathbf{T 2}$} & \multicolumn{2}{|c|}{ T3 } & \multicolumn{2}{|c|}{ T4 } & \multicolumn{2}{|c|}{ T4 } \\
\hline & 2012 & 2013 & 2012 & 2013 & 2012 & 2013 & 2012 & 2013 & 2012 & 2013 \\
\hline $\mathrm{pH}$ & 8.14 & 8.23 & 7.91 & 8.1 & 7.5 & 7.8 & 7.88 & 7.92 & 7.84 & 7.95 \\
\hline$E C(d S / m)$ & 5.35 & 5.45 & 5.21 & 4.84 & 4.99 & 4.45 & 5.68 & 5.98 & 5.29 & 5.48 \\
\hline $\mathrm{CaCO}_{3} \%$ & 17.94 & 18.94 & 13.89 & 14.73 & 8.98 & 9.47 & 10.89 & 11.57 & 5.21 & 4.21 \\
\hline \multicolumn{11}{|c|}{ Soluble Cations (meq/l) } \\
\hline $\mathbf{C a}$ & 6.182 & 5.83 & 4.66 & 5.103 & 4.63 & 4.75 & 3.04 & 3.21 & 5.98 & 7.99 \\
\hline $\mathrm{Mg}$ & 16.32 & 16.62 & 14.68 & 13.32 & 12.83 & 11.58 & 19.69 & 18.66 & 16.57 & 16.25 \\
\hline $\mathrm{Na}$ & 28.79 & 3.52 & 30.56 & 28.30 & 30.14 & 26.79 & 31.93 & 35.22 & 28.77 & 28.38 \\
\hline K & 1.99 & 1.94 & 1.80 & 1.62 & 2.32 & 1.41 & 1.67 & 1.80 & 1.47 & 1.76 \\
\hline \multicolumn{11}{|c|}{ Soluble Anions (meq/l) } \\
\hline $\mathrm{HCO}_{3}$ & 1.54 & 1.64 & 2.20 & 1.86 & 1.82 & 1.61 & 1.91 & 2.21 & 1.94 & 1.90 \\
\hline $\mathrm{Cl}$ & 6.08 & 6.47 & 6.54 & 5.74 & 6.92 & 7.03 & 7.45 & 7.85 & 6.25 & 6.89 \\
\hline $\mathrm{SO}_{4}$ & 45.88 & 46.18 & 42.76 & 40.56 & 40.94 & 35.89 & 47.44 & 49.38 & 44.66 & 45.59 \\
\hline \multicolumn{11}{|c|}{ Available Nutrients $(\mathrm{mg} / \mathrm{kg})$} \\
\hline $\mathbf{K}$ & 1150 & 1150 & 1150 & 1150 & 950 & 950 & 1000 & 1000 & 1125 & 1125 \\
\hline $\mathbf{P}$ & 26.32 & 27.1 & 26.45 & 27.4 & 25.89 & 26.1 & 38.42 & 38.1 & 28.21 & 29.3 \\
\hline $\mathbf{N}$ & 87.65 & 95.84 & 69.58 & 56.45 & 89.74 & $\begin{array}{c}102.4 \\
3\end{array}$ & $\begin{array}{c}100.8 \\
7\end{array}$ & 132.7 & 94.65 & 68.29 \\
\hline
\end{tabular}

(T1) Irrigation throughout the season using agricultural drainage.

(T2) Irrigation with agricultural drainage then using canal water in sequentially.

(T3) Using agricultural drainage water for irrigation at the vegetative growth period then switch to canal water right before panicle initiation till harvest.

(T4) Using canal water at the vegetative growth and agricultural drainage right before panicle initiation then before witch to drainage water till harvest.

(T5) Irrigation throughout the season using canal water.

Table (3). Chemical composition of irrigation water used for the present experiment (2012 and 2013 growing seasons)

\begin{tabular}{|c|c|c|c|c|c|c|c|c|c|c|}
\hline \multirow{2}{*}{\multicolumn{2}{|c|}{ Parameters }} & \multirow{2}{*}{$\begin{array}{c}\mathrm{EC} \\
\mathrm{dS} / \mathrm{m}\end{array}$} & \multirow[b]{2}{*}{ pH } & \multicolumn{4}{|c|}{ Soluble cations (meq/l) } & \multicolumn{3}{|c|}{ Soluble anions (meq/l) } \\
\hline & & & & $\mathrm{Na}^{+}$ & $\mathrm{K}^{+}$ & $\mathrm{Ca}^{2+}$ & $\mathrm{Mg}^{2+}$ & $\mathrm{Cl}^{-}$ & $\mathrm{HCO}_{3}^{-}$ & $\mathrm{SO}_{4}=$ \\
\hline \multirow{2}{*}{2012} & $\begin{array}{l}\text { Canal Water } \\
\text { (inside location) }\end{array}$ & 2.37 & 7.40 & 12.82 & 0.98 & 4.62 & 5.10 & 8.46 & 13.05 & 1.76 \\
\hline & $\begin{array}{l}\text { Drainage Water } \\
\text { (inside location) }\end{array}$ & 2.90 & 7.78 & 18.25 & 1.29 & 6.18 & 3.11 & 12.44 & 13.75 & 2.14 \\
\hline \multirow{2}{*}{2013} & $\begin{array}{l}\text { Canal Water } \\
\text { (inside location) }\end{array}$ & 2.43 & 7.40 & 13.10 & 0.86 & 4.85 & 5.35 & 7.34 & 14.34 & 1.96 \\
\hline & $\begin{array}{l}\text { Drainage Water } \\
\text { (inside location) }\end{array}$ & 2.96 & 7.78 & 18.80 & 1.19 & 6.48 & 3.06 & 11.13 & 15.58 & 2.23 \\
\hline
\end{tabular}

\section{The studied Characters}

1. Quality of irrigation water

Quality of the irrigation water was determined according to the following parameters (Wilcox, 1958 and FAO, 1976):

1. The soluble salts concentration of water, which can be expressed in terms of electrical conductivity $\left(\mathrm{EC}_{\mathrm{iw}}, \mathrm{dS} / \mathrm{m}\right)$.

2. The chemical composition of water, by determining the concentrations of cations $\left(\mathrm{Ca}^{2+}, \mathrm{Mg}^{2+}, \mathrm{Na}^{+}, \mathrm{K}^{+}\right.$and anions $\left(\mathrm{CO}_{3}{ }^{2-}, \mathrm{HCO}_{3}{ }^{-}, \mathrm{Cl}^{-}\right.$and $\mathrm{SO}_{4}{ }^{2-}$ ions $)$ according to Jackson (1973). 
The quality parameters were calculated as follows(Richards, 1972):

a. Sodium Hazard:

Can be expressed in terms of Sodium Adsorption Ratio (SAR) or Soluble

Sodium Percentage (SSP, \%).

$$
\begin{aligned}
\mathrm{SAR} & =\frac{\mathrm{Na}^{+}}{\sqrt{\left(\mathrm{Ca}^{2+}+\mathrm{Mg}^{2+}\right) / 2}} \\
\mathrm{SSP} & =\frac{\mathrm{Na}^{+}}{\sum \text { Cations }} \times 100
\end{aligned}
$$

(The concentration of cations was expressed in me/L).

b. Magnesium hazard (SMgP):

It can be expressed by the value of Soluble Magnesium Percentage (SMgP, \%),

$$
\mathrm{SMgP}=\frac{\left[\mathrm{Mg}^{2+}\right]}{\left[\mathrm{Ca}^{2+}+\mathrm{Mg}^{2+}\right]} \times 100
$$

\section{c. Bicarbonate hazard:}

It can be expressed by the value of Residual Sodium Carbonate (RSC, me/L):

$$
\mathrm{RSC}=\left[\mathrm{CO}_{3}^{2-}+\mathrm{HCO}_{3}^{-}\right]-\left[\mathrm{Ca}^{2+}+\mathrm{Mg}^{2+}\right]
$$

(The concentration of ions was expressed in me/l.)

d. The concentration of toxic compounds can be expressed by the values of Potential Salinity (PS):

$$
\mathrm{PS}(\mathrm{me} / \mathrm{l})=\mathrm{Cl}^{-}+0.5 \times \mathrm{SO}_{4}^{2-}
$$

\section{Growth characters}

1. Number of days to heading (days).

2. Plant height $(\mathrm{cm})$.

3. Panicle length $(\mathrm{cm})$.

\section{Yield and Its components}

1. Number of panicles/hill.

2. Number of filled grains/ panicle.

3. 1000 grains weight.

4. Grain yield ton/fed.

\section{Yield related characters}

\section{Sterility percentage (\%)}

$$
\text { Sterility } \%=\frac{\text { No. of unfilled grains/panicle }}{\text { Total spikelets/panicles }} \times 100
$$

2. Harvest Index (HI)

$$
\text { H.I. }=\frac{\text { Economical yield }(\text { grain yield })}{\text { Biological yield }(\text { grain }+ \text { straw yields })} \times 100
$$

\section{Grain Quality characters (Milling characters)}

1. Hulling \% (Brown rice \%).

$$
\text { Hulling } \%=\frac{\text { Brown rice weight }}{\text { Rough rice weight }(100 \mathrm{~g})} \times 100
$$


2. Milling \% (total white rice \%)

$$
\text { Milling } \%=\frac{\text { Milled rice weight }}{\text { Rough rice weight }(100 \mathrm{~g})} \times 100
$$

\section{Broken rice \%}

$$
\text { Broken rice } \%=\frac{\text { Broken rice weight }}{\text { Rough rice weight }(100 \mathrm{~g})} \times 100
$$

\section{Cooking and Eating Quality}

1. Gel Consistency (G.C.) was measured according to Cagampang et al. (1973)

2. Gelatinization temperature (G.t.) was measured according to little et al.(1958).

\section{Statistical Analysis}

The analysis of variance was carried out according to Gomez and Gomez (1984) and means were compared using the LSD at 0.05 level of significant.

\section{RESULTS and DISCUSSION}

\section{Quality of irrigation water}

The water quality parameters for canal and drainage waters are presented in Table (4). From these data, it appears that for the two types of water, the $\mathrm{EC}_{\mathrm{iw}}$ ranged from 2.37 to $2.96 \mathrm{dS} / \mathrm{m}$. The critical level of $\mathrm{EC}_{\mathrm{iw}}$ to cause severe salinity problems is $3.0 \mathrm{dS} / \mathrm{m}$ as reported by FAO (1976). The values of $\mathrm{EC}_{\mathrm{iw}}$ for canal and drainage waters are less than the critical limit and no problems for using these types of irrigation water. Therefore, it is expected that continuous irrigation without good water management (leaching requirements) can led to severe problems from the salinity point of view.

The data presented in Table (4) also revealed that the SAR (Sodium Adsorption Ratio) value of all water sources is relatively low in comparing with the critical level of sodium hazard (less than 10) as reported by Richards (1972). With respect to the SSP as indicator for sodium hazard, the values of SSP for all types of water were ranged from 54.33 to $63.67 \%$. The data revealed that all values of SSP were around the critical limit $(<60 \%)$ as reported by Wilcox (1958).

Magnesium hazard (Soluble Magnesium Percentage) is one of the criteria for suitability of water for irrigation. In this respect, the values of SMgP in Table (4) indicated that all types of water have a values ranged from 32.05 to $52.50 \%$. The values are below the harmful level (>50\%). This means no problem of Magnesium hazard.

The RSC (Residual Sodium Carbonates) evaluates the tendency of irrigation water to form carbonate and to dissolve or to precipitate calcium and to a less degree, the magnesium carbonate. The precipitation of poorly soluble carbonates increases the sodium hazard of irrigation water and as a result increases the sodicity of irrigated soils. The present values of RSC have values ranged between 3.33 and 6.05 meq/l. which means that $\mathrm{Ca}^{2+}+\mathrm{Mg}^{2+}$ is less than the $\mathrm{CO}_{3}{ }^{2-}+\mathrm{HCO}_{3}^{-}$that resulted in more problems of sodium hazard. Potential salinity (PS) for all water types used ranged from 8.31 to $13.51 \mathrm{meq} / \mathrm{l}$. The high values of PS over the critical level $(5 \mathrm{meq} / \mathrm{l})$ as reported by Richards (1972) may be due to high chloride and sulfate concentrations in the two irrigation waters. 
Generally, from the presented data, it appears that the two water types used in this work may cause one problem or another according to the water type. By applying the criteria used for interpreting water quality for irrigation, the most domain problems are salinity and sodicity hazards.

Table (4). Water quality parameters used as irrigation water in the present study

\begin{tabular}{cccccccc}
\hline Year & Type & $\begin{array}{c}\text { EC } \\
\mathbf{d S} / \mathbf{m}\end{array}$ & $\begin{array}{c}\text { SSP } \\
\%\end{array}$ & SAR & $\begin{array}{c}\text { SMgP } \\
\%\end{array}$ & $\begin{array}{c}\text { RSC } \\
\mathbf{m e q} / \mathbf{l}\end{array}$ & $\begin{array}{c}\mathbf{P S} \\
\mathbf{m e q} / \mathbf{l}\end{array}$ \\
\hline $\mathbf{2 0 1 3}$ & $\begin{array}{c}\text { Canal } \\
\text { (inside location) } \\
\text { Drainage } \\
\text { (inside location) }\end{array}$ & 2.37 & 54.50 & 5.81 & 52.50 & 3.33 & 9.34 \\
& $\begin{array}{c}\text { Canal } \\
\text { (inside location) } \\
\text { Drainage } \\
\text { (inside location) }\end{array}$ & 2.43 & 63.31 & 8.47 & 33.45 & 4.46 & 13.51 \\
\hline
\end{tabular}

\section{Growth characters}

There are high significant differences among the mean values of the four rice cultivars regarding all the growth characters (Number of days to heading, plant height $(\mathrm{cm})$ and panicle length $(\mathrm{cm})$ under study in the two, and this was attributed to the differences in their genetic back ground (Table 5). Additionally, it is clear that all growth characters were affected significantly by different irrigation treatments. However mostly there were insignificant difference between the mean values of T5 (Irrigation throughout the season by canal water) and T3 (Using agricultural drainage water for irrigation till the end of the vegetative growth stage and the canal water starting from reproductive stag) .For No. of days to Heading This might be due to the role of drainage water push the plant to reproduce new canopies to replace the affected one that resulted in prolonging the vegetative phase of crop. From another point of view, the increase in plant height and panicle length might be enhanced by the availability of sufficient water that are necessary for all various biological and physiological processes including cell division and cell elongation of the plant. These results are agree with those results reported that plant height and panicle length significantly decreased as irrigation intervals increased to twelve days (El-Refaaee et al., 2005) or nine days (El-Refaee et al. , 2008) in both seasons. and this might be due to that panicle length was significantly decrease with the increased salinity stress (Shereen et al., 2005 and Mirza et al., 2009). Also, Ernesto et al. (2007) reported that both PEG and $\mathrm{NaCl}$ delayed flowering and maturity, with a longer delay observed with the high-level stress. On the other hand, Gomaa et al. (2005) concluded that plant height, panicle length and No. of days to heading were not significantly affected by different irrigation water forms. Interaction between cultivars and irrigation treatments. in the two seasons, was significant for all growth characters except for leaf area index.

\section{Yield and Its components}

Data represented in Table (6 and 7) showed that there were highly significant differences between the mean values of all cultivars under study regarding yield and yield component characters in cultivars under the conditions of the present study. 
Table (5). Effect of irrigation treatments and rice cultivars on Number of days to heading, plant height, panicle length (in 2012 and 2013 seasons)

\begin{tabular}{|c|c|c|c|c|c|c|c|c|c|c|c|c|}
\hline \multicolumn{13}{|c|}{ Number of days to heading } \\
\hline \multirow{3}{*}{$\begin{array}{c}\text { Cultivars } \\
\text { (C) }\end{array}$} & \multicolumn{5}{|c|}{2012} & \multirow{3}{*}{ Averages } & \multicolumn{5}{|c|}{2013} & \multirow{3}{*}{ Averages } \\
\hline & \multicolumn{5}{|c|}{ Irrigation treatments (T) } & & \multicolumn{5}{|c|}{ Irrigation treatments (T) } & \\
\hline & T1 & T2 & T3 & T4 & T5 & & T1 & $\mathbf{T 2}$ & T3 & T4 & T5 & \\
\hline Hybrid 1 & 96.57 & 95.53 & 93.96 & 94.00 & 94.03 & 94.82 & 96.50 & 95.34 & 94.29 & 93.90 & 94.23 & 94.85 \\
\hline Sakha 104 & 102.7 & 102.10 & 100.26 & 99.94 & 100.03 & 101.01 & 103.27 & 101.84 & 100.19 & 100.11 & 99.90 & 101.06 \\
\hline Giza 177 & 97.20 & 97.20 & 96.37 & 95.09 & 95.23 & 96.22 & 97.27 & 97.07 & 96.21 & 95.09 & 95.06 & 96.14 \\
\hline Giza 178 & 96.06 & 96.56 & 95.63 & 95.77 & 95.77 & 95.96 & 95.99 & 96.36 & 95.43 & 95.54 & 95.57 & 95.78 \\
\hline Averages & 98.13 & 97.85 & 96.56 & 96.20 & 96.27 & 97.00 & 98.26 & 97.65 & 96.53 & 96.16 & 96.19 & 96.96 \\
\hline \multirow{2}{*}{\multicolumn{2}{|c|}{ LSD 0.05}} & $\mathbf{I}$ & $\mathbf{C}$ & \multirow{2}{*}{\multicolumn{2}{|c|}{$\begin{array}{c}\mathbf{I} * \mathbf{C} \\
0.49\end{array}$}} & \multirow{2}{*}{\multicolumn{2}{|c|}{ LSD 0.05}} & $\mathbf{I}$ & $\mathbf{C}$ & \multicolumn{2}{|c|}{$\mathbf{I} * \mathbf{C}$} & \\
\hline & & 0.23 & 0.27 & & & & & 0.30 & 0.22 & & .44 & \\
\hline \multicolumn{13}{|c|}{ Plant height (cm) } \\
\hline \multirow{3}{*}{$\begin{array}{c}\text { Cultivars } \\
\text { (C) }\end{array}$} & \multicolumn{5}{|c|}{2012} & \multicolumn{6}{|c|}{2013} & \multirow{3}{*}{ Averages } \\
\hline & \multicolumn{5}{|c|}{ Irrigation treatments $(\mathrm{T})$} & Averages & \multicolumn{5}{|c|}{ Irrigation treatments $(\mathbf{T})$} & \\
\hline & T1 & $\mathbf{T 2}$ & T3 & T4 & T5 & & T1 & T2 & T3 & T4 & T5 & \\
\hline Hybrid 1 & 92.7 & 91.43 & 92.60 & 93.40 & 93.50 & 92.72 & 93.20 & 92.74 & 94.43 & 93.23 & 94.32 & 93.58 \\
\hline Sakha 104 & 103.0 & 100.37 & 104.2 & 102.4 & 104.27 & 102.91 & 101.81 & 101.74 & 105.56 & 104.13 & 105.63 & 103.77 \\
\hline Giza 177 & 92.5 & 91.56 & 94.27 & 93.77 & 94.27 & 93.27 & 92.03 & 92.93 & 95.83 & 95.08 & 95.90 & 94.35 \\
\hline Giza 178 & 97.4 & 97.46 & 98.53 & 98.47 & 99.47 & 98.27 & 98.53 & 98.43 & 100.41 & 99.54 & 100.56 & 99.49 \\
\hline Averages & 96.5 & 95.21 & 97.4 & 97.01 & 97.88 & 96.79 & 96.39 & 96.46 & 99.06 & 98.00 & 99.10 & 97.80 \\
\hline \multirow{2}{*}{\multicolumn{2}{|c|}{ LSD 0.05}} & I & $\mathbf{C}$ & \multirow{2}{*}{\multicolumn{2}{|c|}{$\frac{\mathbf{I} * \mathbf{C}}{0.47}$}} & \multirow{2}{*}{\multicolumn{2}{|c|}{ LSD 0.05}} & I & $\mathrm{C}$ & \multirow{2}{*}{\multicolumn{2}{|c|}{$\begin{array}{c}\mathbf{I} * \mathbf{C} \\
0.56\end{array}$}} & \\
\hline & & 0.17 & 0.27 & & & & & 0.36 & 0.22 & & & \\
\hline
\end{tabular}




\section{Table (5). Cont...}

\section{Panicle length (cm)}

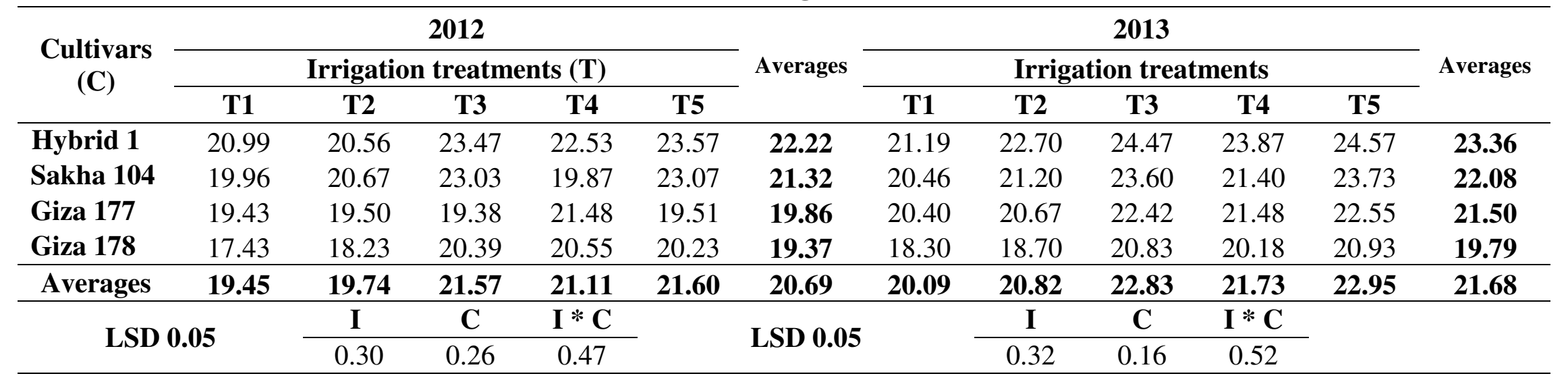

(T1)Irrigation throughout the season using agricultural drainage water.

(T2) Irrigation with agricultural drainage water then using canal water in sequentially.

(T3) Using agricultural drainage water for irrigation till end of the vegetative growth stage and the canal water starting from reproductive stage.

(T4) Using canal water at the vegetative growth stage and agricultural drainage water right before panicle initiation.

(T5) Irrigation throughout the season by canal water: 
Table (6). Effect of irrigation treatments and rice cultivars on Number of panicles/hill and Number of filledgrains/panicle (in 2012 and 2013 seasons)

\begin{tabular}{|c|c|c|c|c|c|c|c|c|c|c|c|c|}
\hline \multicolumn{13}{|c|}{ Number of Panicles/hill } \\
\hline \multirow{3}{*}{$\begin{array}{c}\text { Cultivars } \\
\text { (C) }\end{array}$} & \multicolumn{5}{|c|}{2012} & \multirow{3}{*}{ Averages } & \multicolumn{5}{|c|}{2013} & \multirow{3}{*}{ Averages } \\
\hline & \multicolumn{5}{|c|}{ Irrigation treatments $(\mathbf{T})$} & & \multicolumn{5}{|c|}{ Irrigation treatments(T) } & \\
\hline & T1 & T2 & T3 & T4 & T5 & & T1 & T2 & T3 & T4 & T5 & \\
\hline Hybrid 1 & 17.00 & 18.00 & 26.13 & 25.00 & 26.33 & 22.49 & 18.53 & 17.14 & 25.61 & 24.33 & 25.85 & 22.29 \\
\hline Sakha 104 & 18.00 & 17.4 & 20.67 & 19.3 & 21.23 & 19.32 & 18.17 & 17.61 & 22.07 & 19.73 & 22.23 & 18.00 \\
\hline Giza 177 & 17.00 & 17.33 & 19.77 & 19.13 & 20.33 & 18.71 & 18.40 & 18.17 & 21.51 & 19.47 & 21.70 & 17.00 \\
\hline Giza 178 & 18.00 & 19.03 & 19.60 & 19.37 & 20.2 & 19.24 & 18.93 & 19.50 & 21.77 & 20.31 & 22.01 & 18.00 \\
\hline Averages & $\mathbf{1 7 . 5 0}$ & 17.94 & 21.54 & 20.70 & 22.02 & 19.94 & 18.51 & 18.11 & 22.74 & 20.96 & 22.95 & $\mathbf{1 7 . 5 0}$ \\
\hline \multirow{2}{*}{\multicolumn{2}{|c|}{ LSD 0.05}} & $\mathbf{I}$ & $\mathbf{C}$ & \multirow{2}{*}{\multicolumn{2}{|c|}{ I*C }} & \multirow{2}{*}{\multicolumn{2}{|c|}{ LSD 0.05}} & $\mathbf{I}$ & $\mathbf{C}$ & \multicolumn{2}{|c|}{$\mathbf{I} * \mathbf{C}$} & \\
\hline & & 0.86 & 0.84 & & & & & 0.27 & 0.25 & & .43 & \\
\hline \multicolumn{13}{|c|}{ Number of Filled-grains/panicle } \\
\hline \multirow{3}{*}{$\begin{array}{c}\text { Cultivars } \\
\text { (c) }\end{array}$} & \multicolumn{5}{|c|}{2012} & \multicolumn{6}{|c|}{2013} & \multirow{3}{*}{ Averages } \\
\hline & \multicolumn{5}{|c|}{ Irrigation treatments $(\mathrm{T})$} & Averages & \multicolumn{5}{|c|}{ Irrigation treatments $(\mathbf{T})$} & \\
\hline & T1 & T2 & T3 & T4 & T5 & & T1 & $\mathbf{T 2}$ & T3 & T4 & T5 & \\
\hline Hybrid 1 & 118.20 & 121.00 & 127.88 & 121.67 & 128.53 & 123.46 & 120.20 & 121.14 & 126.63 & 125.33 & 127.53 & 124.17 \\
\hline Sakha 104 & 75.45 & 80.23 & 87.65 & 82.00 & 88.01 & 82.67 & 76.77 & 81.87 & 86.07 & 82.43 & 86.87 & 82.80 \\
\hline Giza 177 & 71.00 & 77.21 & 89.87 & 79.02 & 90.12 & 81.44 & 71.07 & 77.54 & 90.95 & 84.06 & 91.03 & 82.93 \\
\hline Giza 178 & 100.10 & 111.00 & 113.83 & 108.33 & 114.12 & 109.48 & 102.60 & 111.47 & 113.64 & 110.07 & 114.13 & 110.38 \\
\hline Averages & 91.19 & 97.36 & 104.81 & 97.76 & 105.20 & 99.26 & 92.66 & 98.01 & 104.32 & 100.47 & 104.89 & 100.07 \\
\hline \multirow{2}{*}{\multicolumn{2}{|c|}{ LSD 0.05}} & I & $\mathrm{C}$ & \multirow{2}{*}{\multicolumn{2}{|c|}{$\begin{array}{l}\mathbf{I} * \mathbf{C} \\
1.85\end{array}$}} & \multirow{2}{*}{\multicolumn{2}{|c|}{ LSD 0.05}} & I & $\mathrm{C}$ & \multicolumn{2}{|c|}{$\mathbf{I} * \mathbf{C}$} & \\
\hline & & 1.13 & 0.58 & & & & & 1.00 & 1.28 & & .25 & \\
\hline
\end{tabular}

(T1)Irrigation throughout the season using agricultural drainage water.

(T2) Irrigation with agricultural drainage water then using canal water in sequentially.

(T3) Using agricultural drainage water for irrigation till end of the vegetative growth stage and the canal water starting from reproductive stage.

(T4) Using canal water at the vegetative growth stage and agricultural drainage water right before panicle initiation.

(T5) Irrigation throughout the season by canal water 
Table (7). Effect of irrigation treatments and cultivars on grain yield ton/fed and 1000-grains weigh (t in 2012 and 2013 seasons)

\begin{tabular}{|c|c|c|c|c|c|c|c|c|c|c|c|c|}
\hline \multicolumn{13}{|c|}{ Grain yield (ton/fed) } \\
\hline \multirow{3}{*}{$\begin{array}{l}\text { Cultivars } \\
\text { (C) }\end{array}$} & \multicolumn{5}{|c|}{2012} & \multirow{3}{*}{ Averages } & \multicolumn{5}{|c|}{2013} & \multirow{3}{*}{ Averages } \\
\hline & \multicolumn{5}{|c|}{ Irrigation treatments $(\mathrm{T})$} & & \multicolumn{5}{|c|}{ Irrigation treatments $(\mathrm{T})$} & \\
\hline & T1 & T2 & T3 & T4 & T5 & & T1 & $\mathbf{T} 2$ & T3 & T4 & T5 & \\
\hline Hybrid 1 & 4.51 & 4.95 & 4.79 & 4.69 & 5.00 & 4.79 & 4.71 & 5.09 & 5.20 & 4.69 & 5.20 & 4.98 \\
\hline Sakha 104 & 4.02 & 3.95 & 4.08 & 4.10 & 4.17 & 4.06 & 4.26 & 3.92 & 4.24 & 4.20 & 4.25 & 4.17 \\
\hline Giza 177 & 3.18 & 3.60 & 3.70 & 3.70 & 4.10 & 3.66 & 3.45 & 3.47 & 3.63 & 3.70 & 4.13 & 3.68 \\
\hline Giza 178 & 4.55 & 4.85 & 4.59 & 4.83 & 4.80 & 4.72 & 3.81 & 3.75 & 4.62 & 4.17 & 4.79 & 4.23 \\
\hline Averages & 4.07 & 4.34 & 4.29 & 4.33 & 4.52 & 4.31 & 4.06 & 4.06 & 4.42 & 4.19 & 4.59 & 4.26 \\
\hline \multirow{2}{*}{\multicolumn{2}{|c|}{ LSD 0.05}} & $\mathbf{I}$ & $\mathbf{C}$ & \multicolumn{2}{|c|}{$\mathbf{I} * \mathbf{C}$} & \multirow{2}{*}{\multicolumn{2}{|c|}{ LSD 0.05}} & I & $\mathbf{C}$ & \multicolumn{2}{|c|}{$\mathbf{I} * \mathbf{C}$} & \\
\hline & & 0.13 & 0.21 & \multicolumn{2}{|c|}{0.26} & & & 0.20 & 0.19 & \multicolumn{2}{|c|}{ n.s. } & \\
\hline \multicolumn{13}{|c|}{1000 grains weight (gm) } \\
\hline \multirow{3}{*}{$\begin{array}{l}\text { Cultivars } \\
\text { (c) }\end{array}$} & \multicolumn{5}{|c|}{2012} & \multicolumn{6}{|c|}{2013} & \multirow{3}{*}{ Averages } \\
\hline & \multicolumn{5}{|c|}{ Irrigation treatments $(\mathrm{T})$} & Averages & \multicolumn{5}{|c|}{ Irrigation treatments $(\mathrm{T})$} & \\
\hline & T1 & T2 & T3 & T4 & T5 & & T1 & T2 & T3 & T4 & T5 & \\
\hline Hybrid 1 & 21.9 & 20.13 & 21.2 & 21.17 & 21.6 & 21.20 & 21.1 & 21.27 & 21.73 & 20.27 & 21.8 & 21.23 \\
\hline Sakha 104 & 23.43 & 23.83 & 23.3 & 23.67 & 24.8 & 23.81 & 23.6 & 23.7 & 24.03 & 24.77 & 24.13 & 24.05 \\
\hline Giza 177 & 20.03 & 21.2 & 21.27 & 22.63 & 25.77 & 22.18 & 21.1 & 21.07 & 22.63 & 22.63 & 22.8 & 22.05 \\
\hline Giza 178 & 24.1 & 24.25 & 25.02 & 24.16 & 25.33 & 24.57 & 24.03 & 24.05 & 24.11 & 24.73 & 25.13 & 24.41 \\
\hline Averages & 22.37 & 22.35 & 22.70 & 22.91 & 24.38 & 22.94 & 22.46 & 22.52 & 23.13 & 23.10 & 23.47 & 22.93 \\
\hline \multirow{2}{*}{\multicolumn{2}{|c|}{ LSD 0.05}} & I & $\mathbf{C}$ & \multirow{2}{*}{\multicolumn{2}{|c|}{$\begin{array}{l}\mathbf{I} * \mathbf{C} \\
0.74\end{array}$}} & \multirow{2}{*}{\multicolumn{2}{|c|}{ LSD 0.05}} & $\mathbf{I}$ & $\mathbf{C}$ & \multicolumn{2}{|c|}{$\mathbf{I} * \mathbf{C}$} & \\
\hline & & 0.36 & 0.41 & & & & & 0.44 & 0.38 & & 80 & \\
\hline
\end{tabular}

(T1) Irrigation throughout the season using agricultural drainage water.

(T2) Irrigation with agricultural drainage water then using canal water in sequentially.

(T3) Using agricultural drainage water for irrigation till end of the vegetative growth stage and the canal water starting from reproductive stage.

(T4) Using canal water at the vegetative growth stage and agricultural drainage water right before panicle initiation.

(T5) Irrigation throughout the season by canal water 
These findings could be attributed to the differences between their genetic makeup. In addition, it is recognized that all studied characters; number of panicles/hill, number of filled grains/ panicle, grain yield (ton/fed) and 1000 grains weight $(\mathrm{g})$ significantly increased gradually by increasing the dose of canal irrigation water starting from T1(irrigation throughout the season using agricultural drainage water) and ending by T5 (irrigation throughout the season by canal water).Data further revealed that the differences grain yield and its attributes mean values $T(5)$ and $T(3)$ were not significant. These results was also found by Zeng and Shannon (2000) whereas ,tiller number per plant and spikelet number per panicle contributed the most variation in grain weight per plant and spikelet number per panicle were the major causes of yield loss in M202 under salinity. The compensation between spikelets and other yield components was confounded with salinity effects, but was believed to be minor relative to the reduction of spikelets due to salinity and, therefore, not sufficient to offset yield loss even at moderate salt levels. Ernesto et al. (2007) reported that 1,000-grain weight showed significantly decrease when they applied salt $(\mathrm{NaCl})$ and polyethylene glycol-6000 (PEG) as sources of osmotic stress during the reproductive stage than during the vegetative stage. Ascha and Wopereis (2001) explained that Floodwater EC $<2 \mathrm{mS} / \mathrm{cm}$ hardly affected rice yield. For floodwater EC levels $>2 \mathrm{mS} / \mathrm{cm}$, a yield loss of up to 1 t/ha per unit EC $(\mathrm{mS} / \mathrm{cm})$ was observed for salinity stress around PI (at canal water yields of about $8 \mathrm{t} / \mathrm{ha}$ ). Use of a salinity tolerant cultivar reduced maximum yield losses to about $0.6 \mathrm{t} /$ ha per unit EC .Different results were obtained for the interaction between cultivars and irrigation treatments. In the two seasons, this interaction was significant for all yield components, except that of grain yield (ton/fed.) which was not significant in 2012 season only. Also, El-Refaaee et al.(2005) reported that, Sakha 104 and Giza 178 rice cultivars gave nearly the same yield and surpassed the yield of the cultivars, while the short duration cultivars, Giza 177 was highly affected by water stress up to 12 days which caused soil salinty and gave yield reduction by about $47,49,46$, and $51 \%$ over both seasons, respectively compared with continuo's flooding. Generally, Sakha 101, Sakha 104, and Giza 178 rice cultivars can be grown better in the irrigated areas where water is limited as at the end of canals

\section{Yield Related Characters}

Table (8) showed that there were highly significant differences between the mean values of all cultivars in case of some yield related characters; Sterility percentage (\%) and Harvest index (HI) for study in the two seasons. These were attributed to their genetic differences. For irrigation treatments it was recognized that all studied characters increased gradually by increasing the dose of canal water used in irrigation till they maximized at (T5) irrigation throughout the season by canal water completely. This result in accordance with Ascha and Wopereis (2001); Abdullah et al. (2001) and Fabre et al. (2005) who reported that saline conditions affects negatively sterility percentage. Also, The results are in conformity with Zeng and Shannon (2000) who concluded that Harvest index was significantly decreased when salinity was at $3.40 \mathrm{dS} / \mathrm{m}$. As for the interaction between cultivars and nitrogen levels, different results were obtained as it was significant for sterility while, it was not significant in case of straw yield and harvest index, in both seasons. 
Table (8). Effect of irrigation treatments and cultivars on Sterility percentage (\%) and Harvest Index (HI )in 2012 and 2013 seasons:

\begin{tabular}{|c|c|c|c|c|c|c|c|c|c|c|c|c|}
\hline \multicolumn{13}{|c|}{ Sterility percentage $(\%)$} \\
\hline \multirow{3}{*}{$\begin{array}{c}\text { Cultivars } \\
\text { (c) }\end{array}$} & \multicolumn{5}{|c|}{2012} & \multirow{3}{*}{ Averages } & \multicolumn{5}{|c|}{2013} & \multirow{3}{*}{ Averages } \\
\hline & \multicolumn{5}{|c|}{ Irrigation treatments $(\mathrm{T})$} & & \multicolumn{5}{|c|}{ Irrigation treatments ( $\mathbf{T})$} & \\
\hline & T1 & T2 & T3 & T4 & T5 & & T1 & T2 & T3 & T4 & T5 & \\
\hline Hybrid 1 & 9.22 & 9.25 & 7.87 & 9.35 & 7.67 & 8.67 & 10.35 & 6.68 & 8.68 & 6.47 & 8.21 & 8.08 \\
\hline Sakha 104 & 12.27 & 11.85 & 7.47 & 7.98 & 7.59 & 9.43 & 11.59 & 9.24 & 7.28 & 7.14 & 6.79 & 8.41 \\
\hline Giza 177 & 13.41 & 12.49 & 6.78 & 11.31 & 7.22 & 10.24 & 13.40 & 11.08 & 6.59 & 6.94 & 6.18 & 8.84 \\
\hline Giza 178 & 10.63 & 11.37 & 4.99 & 8.08 & 5.01 & 8.02 & 7.78 & 10.92 & 5.49 & 5.17 & 5.26 & 6.92 \\
\hline Averages & 11.38 & 11.24 & 6.78 & 9.18 & 6.87 & 9.09 & 10.78 & 9.48 & 7.01 & 6.43 & 6.61 & 8.06 \\
\hline \multirow{2}{*}{ LSD 0.05} & \multirow{2}{*}{\multicolumn{2}{|c|}{$\frac{\mathbf{I}}{1.19}$}} & $\mathbf{C}$ & \multirow{2}{*}{\multicolumn{2}{|c|}{$\begin{array}{l}\mathbf{I} * \mathbf{C} \\
1.87 \\
\end{array}$}} & \multirow{2}{*}{\multicolumn{2}{|c|}{ LSD 0.05}} & $\mathbf{I}$ & \multicolumn{2}{|c|}{$\mathbf{C}$} & $\mathbf{I} * \mathbf{C}$ & \\
\hline & & & 1.35 & & & & & 0.69 & \multicolumn{2}{|c|}{0.37} & 1.01 & \\
\hline \multicolumn{13}{|c|}{ Harvest Index (HI) } \\
\hline \multirow{3}{*}{$\begin{array}{c}\text { Cultivars } \\
\text { (c) }\end{array}$} & \multicolumn{5}{|c|}{2012} & \multicolumn{6}{|c|}{2013} & \multirow{3}{*}{ Averages } \\
\hline & \multicolumn{5}{|c|}{ Irrigation treatments ( $\mathrm{T})$} & Averages & \multicolumn{5}{|c|}{ Irrigation treatments (T) } & \\
\hline & T1 & T2 & T3 & T4 & T5 & & T1 & T2 & T3 & T4 & T5 & \\
\hline Hybrid 1 & 39.15 & 40.02 & 40.35 & 39.91 & 40.42 & 39.97 & 40.39 & 40.88 & 40.75 & 39.91 & 39.79 & 40.35 \\
\hline Sakha 104 & 40.61 & 39.62 & 39.50 & 40.88 & 40.84 & 40.29 & 40.53 & 39.96 & 40.19 & 41.38 & 39.28 & 40.27 \\
\hline Giza 177 & 39.41 & 39.74 & 40.00 & 40.26 & 41.41 & 40.16 & 39.03 & 39.43 & 39.41 & 40.26 & 41.26 & 39.88 \\
\hline Giza 178 & 39.43 & 39.72 & 40.30 & 40.38 & 40.44 & 40.05 & 40.53 & 40.41 & 41.89 & 40.21 & 39.92 & 40.59 \\
\hline Averages & 39.65 & 39.77 & 40.04 & 40.36 & 40.78 & 40.12 & 40.12 & 40.17 & 40.56 & 40.44 & 40.06 & 40.27 \\
\hline \multirow{2}{*}{ LSD 0.05} & & & $\mathbf{C}$ & & & \multirow{2}{*}{\multicolumn{2}{|c|}{ LSD 0.05}} & I & \multirow{2}{*}{\multicolumn{2}{|c|}{$\begin{array}{c}\mathbf{C} \\
0.95\end{array}$}} & C*I & \\
\hline & & & 0.83 & & & & & 0.87 & & & n.s. & \\
\hline
\end{tabular}

(T1) Irrigation throughout the season using agricultural drainage water.

(T2) Irrigation with agricultural drainage water then using canal water in sequentially.

(T3) Using agricultural drainage water for irrigation till end of the vegetative growth stage and the canal water starting from reproductive stage.

(T4) Using canal water at the vegetative growth stage and agricultural drainage water right before panicle initiation.

(T5) Irrigation throughout the season by canal water 
Table (9). Effect of irrigation treatments and cultivars on Hulling percentage (\%), Milling percentage and Broken grains percentage in 2012 and 2013 seasons:

\begin{tabular}{|c|c|c|c|c|c|c|c|c|c|c|c|c|}
\hline \multicolumn{13}{|c|}{ Hulling percentage } \\
\hline \multirow{3}{*}{$\begin{array}{c}\text { Cultivars } \\
\text { (C) }\end{array}$} & \multicolumn{5}{|c|}{2012} & \multirow{3}{*}{ Averages } & \multicolumn{5}{|c|}{2013} & \multirow{3}{*}{ Averages } \\
\hline & \multicolumn{5}{|c|}{ Irrigation treatments $(\mathbf{T})$} & & \multicolumn{5}{|c|}{ Irrigation treatments(T) } & \\
\hline & T1 & $\mathbf{T 2}$ & T3 & T4 & T5 & & T1 & $\mathbf{T 2}$ & T3 & T4 & T5 & \\
\hline Hybrid 1 & 84.28 & 81.44 & 82.00 & 81.57 & 79.88 & 81.83 & 84.42 & 84.2 & 81.64 & 81.57 & 80.22 & 82.41 \\
\hline Sakha 104 & 80.98 & 80.75 & 80.40 & 81.25 & 79.22 & 81.25 & 83.54 & 84.32 & 80.26 & 82.92 & 79.79 & 82.27 \\
\hline Giza 177 & 82.37 & 81.12 & 81.42 & 82.13 & 79.04 & 81.42 & 82.24 & 82.2 & 81.45 & 81.12 & 80.49 & 81.9 \\
\hline Giza 178 & 82.42 & 81.47 & 79.78 & 82.09 & 79.78 & 80.71 & 82.22 & 82.4 & 80.2 & 81.39 & 80.58 & 81.36 \\
\hline Averages & 83.67 & 80.47 & 80.90 & 81.26 & 79.48 & 81.30 & 83.48 & 83.53 & 80.89 & 81.75 & 80.27 & 81.98 \\
\hline \multirow{2}{*}{\multicolumn{2}{|c|}{ LSD 0.05}} & $\mathbf{C}$ & I & \multirow{2}{*}{\multicolumn{2}{|c|}{$\mathbf{C * I}$}} & \multirow{2}{*}{\multicolumn{2}{|c|}{ LSD 0.05}} & $\mathrm{C}$ & I & \multicolumn{2}{|c|}{ C*I } & \\
\hline & & n.s. & 0.52 & & & & & 0.22 & 0.42 & \multicolumn{2}{|c|}{0.79} & \\
\hline \multicolumn{13}{|c|}{ Milling percentage } \\
\hline \multirow{3}{*}{$\begin{array}{c}\text { Cultivars } \\
\text { (C) }\end{array}$} & \multicolumn{5}{|c|}{2012} & \multicolumn{6}{|c|}{2013} & \multirow{3}{*}{ Averages } \\
\hline & \multicolumn{5}{|c|}{ Irrigation treatments $(\mathrm{T})$} & Averages & \multicolumn{5}{|c|}{ Irrigation treatments( $\mathrm{T})$} & \\
\hline & T1 & $\mathbf{T 2}$ & T3 & $\mathbf{T 4}$ & T5 & & T1 & $\mathbf{T 2}$ & T3 & T4 & T5 & \\
\hline Hybrid 1 & 73.65 & 71.37 & 70.81 & 71.04 & 69.28 & 71.23 & 73.79 & 71.57 & 70.95 & 71.41 & 69.68 & 71.48 \\
\hline Sakha 104 & 72.34 & 72.73 & 71.77 & 72.12 & 70.95 & 71.98 & 75.12 & 75.69 & 71.29 & 74.29 & 71.63 & 73.60 \\
\hline Giza 177 & 71.1 & 71.34 & 70.09 & 70.13 & 68.01 & 70.13 & 71.03 & 70.71 & 70.17 & 70.21 & 70.21 & 70.47 \\
\hline Giza 178 & 73.44 & 73.58 & 72.2 & 72.58 & 72.04 & 72.77 & 73.33 & 73.84 & 71.84 & 72.51 & 71.31 & 72.57 \\
\hline Averages & 72.63 & 72.26 & 71.22 & 80.47 & 70.07 & 71.53 & 73.32 & 72.95 & 71.06 & 72.11 & 70.71 & 72.03 \\
\hline \multirow{2}{*}{\multicolumn{2}{|c|}{ LSD 0.05}} & I & $\mathrm{C}$ & \multirow{2}{*}{\multicolumn{2}{|c|}{$\frac{1 \cdot \mathbf{C}}{0.58}$}} & \multirow{2}{*}{\multicolumn{2}{|c|}{ LSD 0.05}} & I & $\mathrm{C}$ & \multicolumn{2}{|c|}{$\mathbf{I} * \mathbf{C}$} & \\
\hline & & 0.42 & 0.38 & & & & & 0.43 & 0.27 & \multicolumn{2}{|c|}{0.75} & \\
\hline
\end{tabular}


Table (9). Cont......

\section{Broken grains percentage}

\begin{tabular}{|c|c|c|c|c|c|c|c|c|c|c|c|c|}
\hline \multirow{3}{*}{$\begin{array}{c}\text { Cultivars } \\
\text { (C) }\end{array}$} & \multicolumn{5}{|c|}{2012} & \multirow{3}{*}{ Averages } & \multicolumn{5}{|c|}{2013} & \multirow{3}{*}{ Averages } \\
\hline & \multicolumn{5}{|c|}{ Irrigation treatments(T) } & & \multicolumn{5}{|c|}{ Irrigation treatments(T) } & \\
\hline & T1 & $\mathbf{T 2}$ & T3 & T4 & T5 & & T1 & T2 & T3 & T4 & T5 & \\
\hline Hybrid 1 & 10.87 & 10.41 & 9.46 & 9.55 & 9.85 & 10.03 & 10.54 & 10.21 & 9.79 & 9.81 & 9.54 & 9.98 \\
\hline Sakha 104 & 9.31 & 9.14 & 8.36 & 8.27 & 8.08 & 8.63 & 9.50 & 9.64 & 8.13 & 8.35 & 8.00 & 8.72 \\
\hline Giza 177 & 10.03 & 9.21 & 9.69 & 10.51 & 9.60 & 9.81 & 9.91 & 9.14 & 9.70 & 10.11 & 9.68 & 9.71 \\
\hline Giza 178 & 6.93 & 6.34 & 6.19 & 6.28 & 5.98 & 6.34 & 6.71 & 6.58 & 6.42 & 6.25 & 6.18 & 6.43 \\
\hline Averages & 9.29 & 8.78 & 8.43 & 80.47 & 8.38 & 8.70 & 9.17 & 8.89 & 8.51 & 8.63 & 8.35 & 8.71 \\
\hline \multirow{2}{*}{\multicolumn{2}{|c|}{ LSD 0.05}} & I & $\mathrm{C}$ & \multirow{2}{*}{\multicolumn{2}{|c|}{$\frac{\mathbf{I} * \mathbf{C}}{0.68}$}} & \multirow{2}{*}{\multicolumn{2}{|c|}{ LSD 0.05}} & I & \multirow{2}{*}{\multicolumn{2}{|c|}{$\begin{array}{c}\mathbf{C} \\
0.51\end{array}$}} & & \\
\hline & & 0.45 & 0.36 & & & & & 0.65 & & & 0.86 & \\
\hline
\end{tabular}

(T1) Irrigation throughout the season using agricultural drainage water.

(T2) Irrigation with agricultural drainage water then using canal water in sequentially.

(T3) Using agricultural drainage water for irrigation till end of the vegetative growth stage and the canal water starting from reproductive stage.

(T4) Using canal water at the vegetative growth stage and agricultural drainage water right before panicle initiation.

(T5) Irrigation throughout the season by canal water 
Table (10). Effect of irrigation treatments and cultivars on Gel Consistency (G.c.) and Gelatinization temperature (G.t.) in 2012 and 2013 seasons:

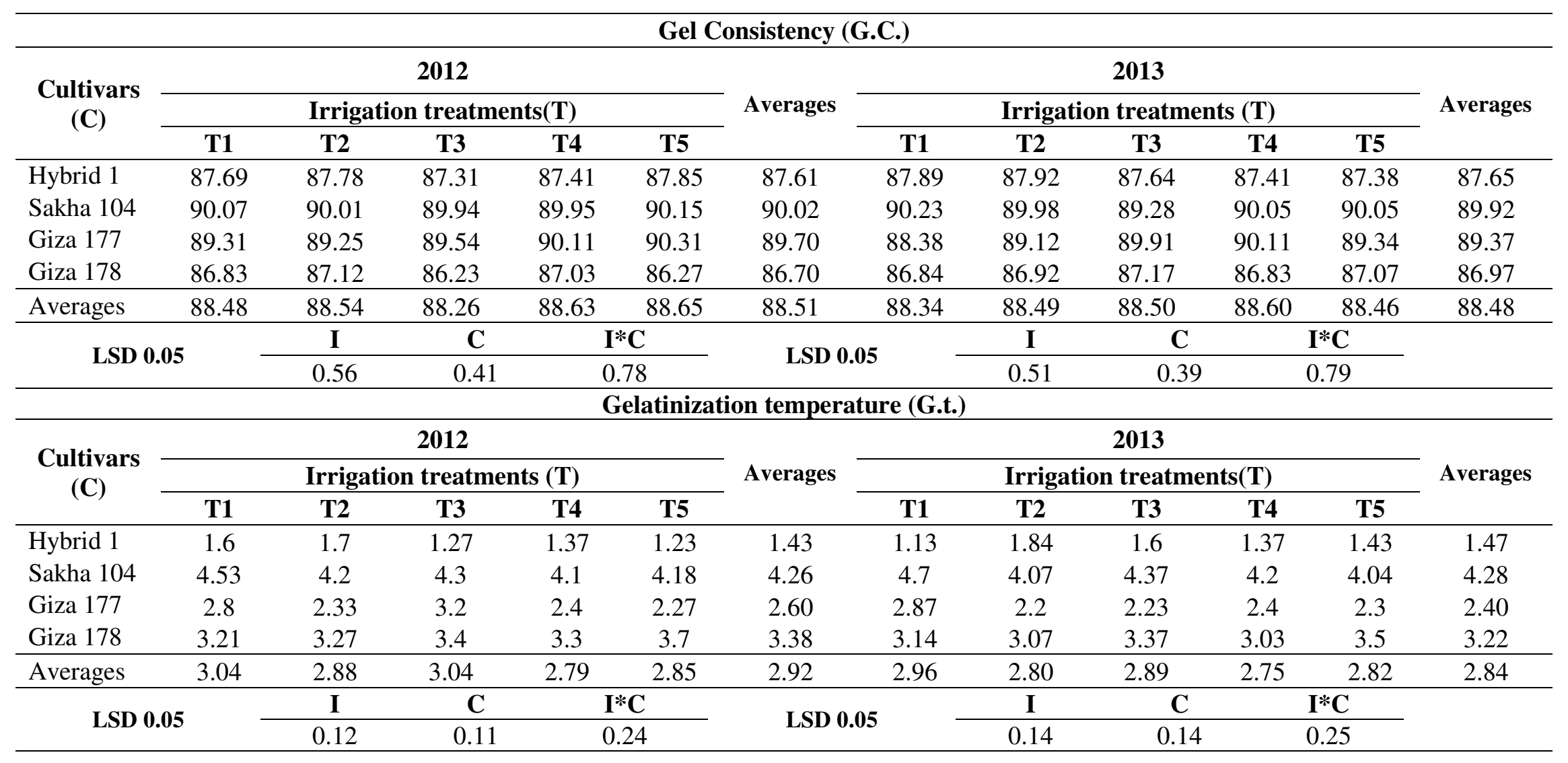

(T1) Irrigation throughout the season using agricultural drainage water.

(T2) Irrigation with agricultural drainage water then using canal water in sequentially.

(T3) Using agricultural drainage water for irrigation till end of the vegetative growth stage and the canal water starting from reproductive stage.

(T4) Using canal water at the vegetative growth stage and agricultural drainage water right before panicle initiation.

(T5) Irrigation throughout the season by canal water 


\section{Grain Quality characters (Milling characters)}

Table(9) indicated that the differences between the four tested rice cultivars regarding milling characters were significant in the two seasons. These differences might be due to almost their different genetic background. Irrigation throughout the season using agricultural drainage water (T1) caused the highest percentages of hulling and milling percentages, also it produced the highest percentage of broken grains in the two seasons. In contrary the lowest hulling and milling percentages and the lowest percentage of broken and chalky grains were found at $\mathrm{T}(5)$ treatment when canal water used in irrigation throughout the season. It is obvious that increasing the dose of the canal water used in irrigation under the present study might improve grain filling processes at the caryopsis of the spikelet's which caused heaviest brown rice and lightest hulls. But increasing the dose of drainage water for rice irrigation might be caused male formation of grain endosperm that produced more brittle caryopsis which led to high broken percentage. The interaction between rice cultivars and irrigation treatments on milling characters was significant in the two seasons. It is worthy to note that mean values of the tested cultivars regarding all milling characters were improved gradually with increasing the quantity of canal water used in irrigation.

\section{Cooking and Eating Quality}

There were significant differences between the mean values among cultivars except cultivars effect of amylase content in the first season regarding all the cooking and eating quality characters under study in the two seasons (Table, 10). While among the cultivars Sakha 104 followed by Giza177 rice cultivars were proved to has the softer GC in both seasons. This varietal variation might be due to their differences in their genetic makeup. Additionally, it is revealed that all studied characters; Gel Consistency (GC) and Gelatinization temperature (GT) increased gradually by increasing the dose of canal water used in the irrigation in different growth stages. Different results were obtained for the interaction between cultivars and irrigation treatments. In the two seasons, this interaction was significant for all cooking and eating quality characters the two seasons of study.

\section{CONCLUSION}

This study recommend using rice cultivar Giza 178 as the best cultivar among studied characters under the same soil and water condition. In addition using agricultural drainage water for irrigation till the end of the vegetative growth stage. Irrigation by canal water starting from reproductive stage gave same results as irrigation throughout the season by canal water for most of studied characters including grain yield. Rice is salt-sensitive (Shannon, 1997). The threshold for yield reduction is $3 \mathrm{dS} / \mathrm{m}$ of electric conductivity in the saturated soil past extract $\left(E_{\mathrm{e}}\right)$, with 90 percent yield loss at $10 \mathrm{dS} / \mathrm{m} \mathrm{EC}$. Rice is relatively salt tolerant during germination, tillering, and toward maturity, but is sensitive during early seedling and at flowering and grain filling. 


\section{REFERENCES}

Abdullah, Z., A. Mushtaq Khan and T. J. Flowers (2001). Causes of Sterility in Seed Set of Rice under Salinity Stress.Journal of Agronomy and Crop Science (Impact Factor: 2.62). 12/2001; 187(1):25 - 32.

Allam, A. andA. Wahba (2008). Egypt to Urge Farmers to Cut Rice Plantations in Favor of Corn .http://www.bloomberg.com/apps/news? Pid= newsarchive\&sid=ackIDtfBrt1 $\mathrm{k}$

Ascha, F., M. C.S. Wopereis. (2001). Responses of field-grown irrigated rice cultivars to varying levels of floodwater salinity in a semi-arid environment. Field Crops Research, 70( 2):127-137.

Black, A., D.D. Evans, L.E. Ensmiger, J.L. white and F.E. Clarck (1965). Methods of Soil Analysis (chemicals and microbiology properties, part 2). Ames. Soc. Of Agron., Madison, Wisconsin.

Cagampang, B.G., C.M. Perez and B.O. Juliano (1973). A gel consistency test for eating quality rice. J. Sci. Food and Agric., 24(1): 589-594.

El-Mowelhi, N.M., S.M. Abo-Soliman, S.M. Barbary and M.I. El-Shahawy (2006). Agronomic aspects and environmental impact of reusing marginal water in irrigation: a case study from Egypt. Water Sci. Technol., 53(9): 229-37.

El-Refaee, I. S., A. E. Abd E-Wahab and S.A. Ghanem (2005). Physiological performance and yield of some rice cultivars as affected by different irrigation interval. Egypt, J. Agric. Res., 83 (5B),

El-Refaee, I. S., A. Al-Ekhtyar and A. Al-Gouhary(2008). Improving Rice Productivity Using Irrigation Intervals and Nitrogen Fertilizer. The Second Field Crops Conference (ABSTRACTS) 36 AGRON-02. 14-16 Oct.

Ernesto,C. G., T. T. Phuc, M. I. Abdelbari and I. Kazuyuki (2007). Response to Salinity in Rice: Comparative Effects of Osmotic and Ionic Stresses. Plant Production Science J., 10(2): 159-170

Fabre D., P.L. Siband and M. Dingkuhn (2005). Characterizing stress effects on rice grain development and filling using grain weight and size distribution. Field crops research, 92 (1): 11-16.

FAO (1976). Water quality for Agriculture. Irrigation and Drainage paper 29, R.S. Ayers and D.W. Westcot.

FAO (2006). Summaries of case studies from Central Asia, Egypt, India, Pakistan and the United States of America. Agricultural Drainage Water Management in Arid and Semi-Arid Areas book. Published by Scientific Publishers (2006-02-07).

Gomaa, M.H., A.A. El-hissewy, F.I. Radwan and M.M. El-siginy (2005). The influence of some irrigation water sourses and nitrogen levels on growth and productivity of rice under newly reclaimed soil conditions. Egypt, J. Agric. Res., 83 (5B).

Little, R.R. , G.B. Hilder and E.H. Dawson (1958). Differential effect of dilute alkali on 25 variteis of milled rice. Cereal Chem., 35: 111-126.

Mirza, H., M. Fujita, M. N. Islam, K. U. Ahamed and N. Kamrun (2009). Performance of four irrigated rice varieties under different levels of salinity stress. IJIB, 6 (2):85-90. 
National Rice Campaign booklet (2012). Rice Researches Department ,Agricultural Research Center (ARC), Ministry of Agriculture, Egypt. (In Arabic)

Richards, L.A. (ed.) (1972). Diagnosis and Improvement of Saline and Alkaline Soils. U.S. Dept. of Agric., Agric. Handbook No. 60.

Shannon, M.C. (1997). Adaptation of plants to salinity. Advances in Agronomy, 60: $75-120$.

Shereen, A., S. Mumtaz, S. Raza, M.A. Khan and S. Solangi (2005). Salinity effects on seedling growth and yield components of different inbred rice lines. Pak. J. Bot., 37(1): 131-139.

Wilcox, L.V. (1958). Determining quality of irrigation water. Agric. Inf. Bull. No. 147, USDA, Washington.

Zeng, L. and M.C. Shannon (2000). Salinity effects on seedling growth and yield components of rice. Crop Sci., 40: 996-1003

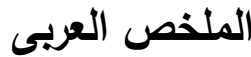

\section{تأثير الرى بمياه الصرف الزراعى على محصول وجودة بعض أصناف الأرز}

$$
\begin{aligned}
& \text { (')محمد عبد العزيز جمعة ،('إبراهيم فتح الله رحاب ، (')جمال عبد الناصر خليل } \\
& \text { (r) } \\
& \text { (') كلية الزراعة سابا بانثا - جامعة الاسكندربة -جمهورية مصر العربية }
\end{aligned}
$$

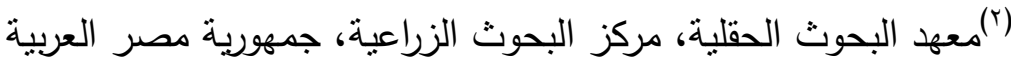

أجريت تجربة حقلية بالمزرعة البحثية التابعة لكلية الزراعة (سابا باشـا)، جامعة الاسكندرية، جمهورية مصر العربية بمنطقة

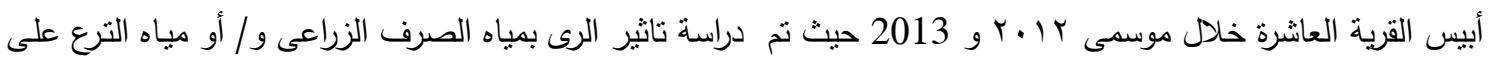
صفات النمو، المحصول ومكوناته وجودة الحبوب لاربعة أصناف من الارز . وكانت معاملات الري كما يلي: أ- الرى طوال موسم بإستخدام مياه الصرف الزراعى. ب - إستخدام رية من الصرف الزراعى ثم رية من مياه التزعة.

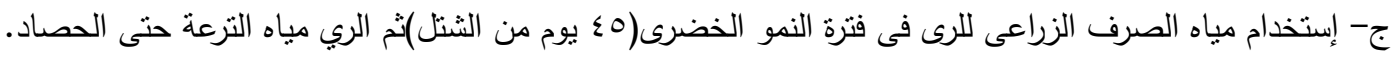

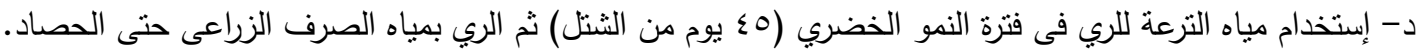
هـ -الرى طوال الموسم بإستخدام مياه الترعة.

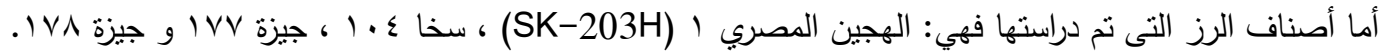

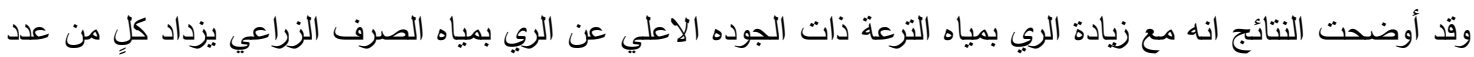
الايام حتى الطرد، طول النبات (سم)، طول السنبله (سم)، عدد السنابل/الجورة، عدد الحبوب المثنلئة/السنبله، محصول الحبوب (طن/فدان)، وزن . . احبة(جم)، النسبة المئوية للجبوب العقيمة (\%)، دليل الحصاد، النسبة المئوية للتقشير، النسبة

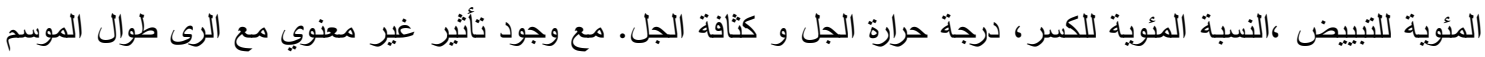

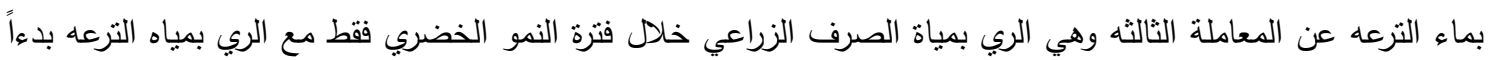


من مرحلة تكوين السنابل (بداية النمو الثمري) حتى الحصاد .التداخل كان ذو ثأثير معنوى لمعظم الصفات الددروسة ماعدا

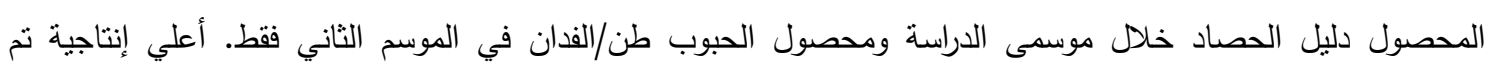

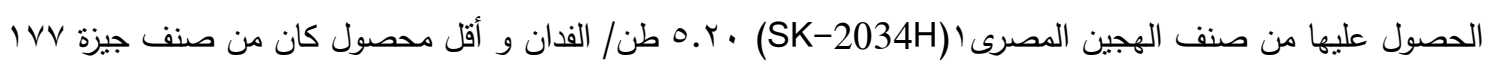

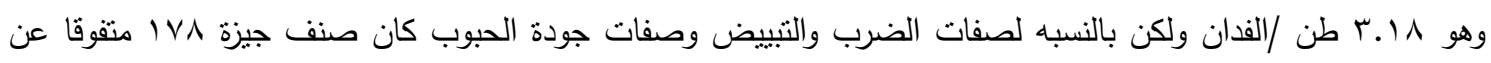

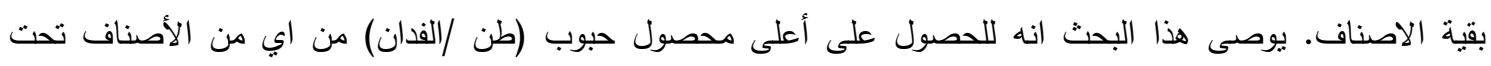

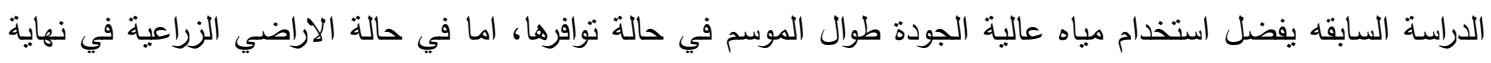

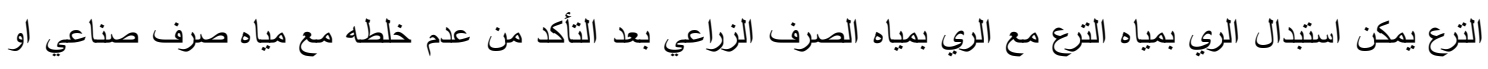

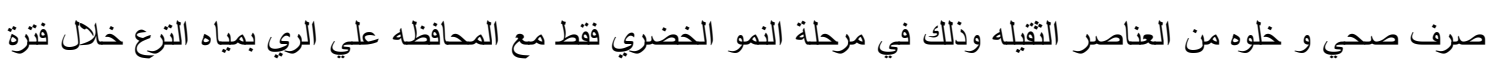
تكوين السنابل و حتي ما قبل الحصاد. 
